\title{
Systematic effects on activity, milk yield, milk flow rate and electrical conductivity
}

\begin{abstract}
Summary
The traits activity, milk yield, milk flow rate and electrical conductivity were analysed in preparation for automatic oestrus detection. Collection of data was performed on a commercial dairy farm and milking took place in a rotary milking parlour. Between February and December 1998 1,090,031 observations from 2,422 Holstein Friesian cows were accumulated. Around $30 \%$ of cows were milked thrice daily. For each trait and each cow a daily value was calculated. The fixed effects test day, parity, calving season, milking frequency, week of lactation and the random effect cow were considered in statistical analyses.

With increasing number of parity, activity decreased and milk yield, milk flow rate and electrical conductivity increased. The milking frequency had significant influence on all analysed traits and for the effect calving season no consistent trend was found. All traits showed characteristic patterns during lactation. Between test days high variations were found for the trait activity. The remaining traits showed a steady level except for small fluctuations. Repeatability was $27.4 \%$ for activity and between 70 and $78.7 \%$ for the milk parameters. The repeatabilities verified the collected field data having a satisfying structure for application in automatic oestrus detection. The repeatability of the trait activity indicated high differences between and within cows. The right skewed distribution indicated the activity as a promising trait for further analyses.
\end{abstract}

Key Words: activity, milk yield, milk flow rate, electrical conductivity, field data, repeatability

\section{Zusammenfassung}

Titel der Arbeit: Systematische Einflussfaktoren auf die Merkmale Bewegungsaktivität, Milchmenge, durchschnittliches Minutengemelk und elektrische Leitfähigkeit

Als Vorarbeiten für die automatische Brunsterkennung wurden die Merkmale Aktivität, Milchmenge, durchschnittliches Minutengemelk und elektrische Leitfähigkeit statistisch analysiert. Die Datenerfassung erfolgte auf einem Praxisbetrieb mit Melkkarussell, in dem ca. 30\% der Kühe dreimal täglich gemolken wurden. Während des Untersuchungszeitraumes von Februar bis Dezember 1998 wurden 1.090.031 Beobachtungen von 2422 Milchkühen erfasst. Als fixe Effekte wurden die Merkmale Testtag, Laktationsnummer, Kalbesaison, Melkfrequenz und Laktationswoche berücksichtigt und als zufälliger Effekt die Kuh.

Mit steigender Laktationsnummer sanken die Aktivität und die Milchmenge, das durchschnittliche Minutengemelk und die elektrische Leitfähigkeit stiegen an. Die Melkfrequenz war für die analysierten Merkmale signifikant. Die Kalbesaison zeigte keinen gerichteten Einfluss. Die Merkmale zeigten im Verlauf der Laktation charakteristische Muster. Für das Merkmal Aktivität wurden starke Schwankungen zwischen den Testtagen gefunden. Die anderen Merkmale zeigten ein gleichmäßigeres Niveau. Die Wiederholbarkeiten betrugen für das Merkmal Bewegungsaktivität 27,4\% und für die Milchmerkmale 70 bis 78,7\%. Aufgrund dieser Ergebnisse konnte gezeigt werden, dass die gesammelten Felddaten eine geeignete Struktur für eine Anwendung zur automatischen Brunsterkennung aufweisen. Die Wiederholbarkeit des Merkmals Bewegungsaktivität zeigte deutliche Unterschiede sowohl zwischen den Kühen als auch innerhalb der Kühe. Die rechtsschiefe Verteilung macht die Bewegungsaktivität zu einem vielversprechenden Merkmal für weitere Analysen.

Schlüsselwörter: Bewegungsaktivität, Milchmenge, Durchschnittliches Minutengemelk, Elektrische Leitfähigkeit, Felddaten, Wiederholbarkeit 


\section{Introduction}

Income in milk production is directly influenced by reproductive performance. For example, increased calving intervals lead to a reduction of milk yield per cow and year, an increased number of replaced heifers, a reduced genetic impact on traits with economic importance and an increased amount of voluntary and involuntary culling (BRITT, 1985). MACK (1996) calculated costs between 0.59 and $1.17 €$ per day for prolonged calving interval. A decrease in conception rate of $1 \%$ results in costs of $1.52 €$ per cow and year (BOICHARD, 1990).

An effective possibility to improve fertility performance is to intensify oestrus detection. Efficient oestrus detection by visual observation is time-consuming and requires diligent attention. As pointed out by ERADUS et al. (1992) visual oestrus detection is especially difficult to realise in large herds. Despite twice daily observation periods, 32\% of oestrus are undetectable (WILLIAMS et al., 1981). Oestrus detection can be simplified and improved by application of technical equipment. Automatically measurable traits promise successful oestrus detection results. Several traits for univariate and multivariate oestrus detection are presented in a literature review of FIRK et al. (2001).

In this investigation, the traits activity, milk yield, milk flow rate and electrical conductivity are analysed concerning the influence of the fixed effects test day, parity, calving season, milking frequency and week of lactation. Additionally, the random effect of the cow was considered. In preparation for further analyses of automatic oestrus detection on the basis of field data, the reliability of data collection should be proved by calculation of the repeatability of the traits.

\section{Material and Methods}

Collection of data was performed between February and December 1998 on a commercial dairy farm. During this observation period 1,090,031 observations from 2,422 Holstein Friesian cows were accumulated. Milking took place in a rotary milking parlour with 36 places. Around 360 cows in early lactation and with high milk yield were milked thrice daily. Remaining cows were milked twice daily.

Activity was measured by a pedometer, which was attached at the left foreleg. The measurement unit of the pedometer was a mercury switch, which was turned off and on by movement of the cow leg. The switch counted the number of connections between mercury and contact from 0 to 999 and started again with 0 . Pedometer measurements were recorded at the entrance of the milking parlour and sent to the herd management computer. Activity was calculated out of the difference between two successive pedometer readings and the period of time between these readings. Consequently, the unit of activity is the number of connections per hour. All measured and calculated data are automatically daily saved in a data set and are available for further processing. This data forms the input values for the analyses. Activity of morning and evening measurements were both 3.8. These values did not differ significantly during the observation period. Accordingly, for each cow a daily mean was calculated. If only one observation per day was available, this observation was deleted.

Milk yield, milk flow rate and electrical conductivity were recorded at each milking. For the trait milk yield a single mean for each cow and each day was calculated. Unit of milk yield was $\mathrm{kg}$ per day. The milk flow rate was calculated as $\mathrm{kg}$ per minute on 
basis of the total milk yield. The electrical conductivity was measured by a special unit of the measuring device. A measurement unit of 500 corresponded approximately to a value of $6 \mathrm{mS}$ per $\mathrm{cm}$. The milk flow rate and the electrical conductivity were weighted by the corresponding milk yield after each milking. By weighting these traits, differences concerning the different milking frequencies and concerning the different levels of milk yield are eliminated. The weighted values of each trait were processed to a daily value for each cow. Days with only one observation were not considered in further analyses.

Due to the calculation of daily values, the data sets reduced by 42 to $44 \%$ for activity and the remaining traits, respectively (Table 1).

Table 1

Number and rate of observations depending on the trait for original data, daily values and statistical analysis (Absolute und relative Anzahl der Beobachtungen der Merkmale des Originaldatensatzes, der Tagesmittelwerte und der statistischen Analyse)

\begin{tabular}{lrrrr}
\hline & \multicolumn{1}{c}{ Activity } & Milk yield & Milk flow rate & Electrical conductivity \\
\hline Original data & 1.090 .031 & 1.090 .031 & 1.090 .031 & 1.090 .031 \\
Daily values & 459.666 & 484.890 & 484.890 & 484.890 \\
& $42.2 \%$ & $44.5 \%$ & $44.5 \%$ & $44.5 \%$ \\
Observations for & 211.061 & 272.741 & 237.552 & 272.614 \\
analysis & $19.4 \%$ & $25.0 \%$ & $21.8 \%$ & $25.0 \%$ \\
\hline
\end{tabular}

A further reduction of data was caused by incorrectly identified records, error readings of the pedometer, deleted observations when milk yield was less then $1.5 \mathrm{~kg}$ per day and deleted herd test days when the number of observations was too small. Observations of the first week of lactation and observations after the $30^{\text {th }}$ week of lactation were not considered in statistical analysis. In the first week of lactation the cows rested in the calving area because of the colostrum period. Additionally, during both periods the distribution of thrice daily milked cows was unsuitable for statistical analysis. After the $30^{\text {th }}$ week of lactation only $2.9 \%$ of milkings originated from thrice daily milked cows. Least observations for analysis were available for the trait activity with 211.061.

The mean, the standard deviation, the minimum and the maximum value for the traits activity, milk yield, milk flow rate and electrical conductivity are presented at Table 2.

Table 2

Mean $(\bar{x})$, standard deviation (s), minimum (Min.) and maximum value (Max.) for the traits activity, milk yield, milk flow rate and electrical conductivity (Mittelwerte, Standardabweichungen, niedrigster und höchster Wert für die Merkmale Bewegungsaktivität, Milchmenge, durchschnittliches Minutengemelk und elektrische Leitfähigkeit)

\begin{tabular}{lccrrrrr}
\hline Trait & Unit & $\begin{array}{c}\text { Number of } \\
\text { observations }\end{array}$ & $\begin{array}{c}\text { Number of } \\
\text { cows }\end{array}$ & $\bar{x}$ & s & Min. & Max. \\
\hline Activity & contacts/h & 211061 & 2090 & 4.2 & 2.1 & 0.6 & 69.9 \\
Milk yield & $\mathrm{kg} /$ day & 272741 & 2201 & 30.2 & 7.4 & 3.7 & 67.4 \\
Milk flow rate & $\mathrm{kg} / \mathrm{min}$ & 237552 & 2198 & 2.2 & 0.5 & 0.3 & 8.2 \\
$\begin{array}{l}\text { Electrical } \\
\text { conductivity }\end{array}$ & units & 272614 & 2199 & 495.0 & 49.0 & 231.0 & 925.0 \\
\hline
\end{tabular}

All traits were tested for normal distribution, skewness and excess using the SAS procedure univariate (SAS, 1992). 
The mean for the trait activity was 4.2 and the corresponding standard deviation was 2.1. The maximum value of 69.9 pointed for right skewness, and was confirmed by a skewness of 6.3. Kurtosis was 89.8.

The trait milk yield shows also a high degree of variation with 3.7 to $67.4 \mathrm{~kg}$ per day. The mean was 30.2 and the standard deviation 7.4. The values for the median, skewness and kurtosis of 29.1, 0.5 and 0.01, respectively, verified that the trait milk yield is normally distributed.

The traits milk flow rate and electrical conductivity showed almost a normal distribution.

After preliminary investigations the fixed effects number of milkings per day, parity, calving season, week of lactation and test day were considered in statistical analyses. The distribution of fixed effects is presented in Table 3.

Table 3

Distribution of observations for the fixed effects (Verteilung der Beobachtungen der fixen Effekte)

\begin{tabular}{|c|c|c|c|c|c|}
\hline Fixed effects & Classes & Activity & Milk yield & Milk flow rate & $\begin{array}{c}\text { Electrical } \\
\text { conductivity }\end{array}$ \\
\hline $\begin{array}{l}\text { Number of milkings } \\
\text { per day }\end{array}$ & $\begin{array}{l}2 \\
3\end{array}$ & $\begin{array}{r}143.132 \\
67.929\end{array}$ & $\begin{array}{r}188.267 \\
84.474\end{array}$ & $\begin{array}{r}162.444 \\
75.108\end{array}$ & $\begin{array}{r}188.156 \\
84.458\end{array}$ \\
\hline Parity & $\begin{array}{r}1 \\
2 \\
3 \\
>3\end{array}$ & $\begin{array}{l}63.579 \\
60.694 \\
37.123 \\
49.665\end{array}$ & $\begin{array}{l}88.241 \\
77.792 \\
45.036 \\
61.672\end{array}$ & $\begin{array}{l}76.277 \\
67.514 \\
39.763 \\
53.998\end{array}$ & $\begin{array}{l}88.209 \\
77.761 \\
45.013 \\
61.631\end{array}$ \\
\hline Calving season & $\begin{array}{r}1997 \\
19981 \\
19982 \\
19983\end{array}$ & $\begin{array}{l}57.046 \\
69.354 \\
56.585 \\
28.076\end{array}$ & $\begin{array}{l}77.042 \\
97.827 \\
66.650 \\
31.222\end{array}$ & $\begin{array}{l}65.415 \\
77.824 \\
63.125 \\
31.188\end{array}$ & $\begin{array}{l}77.005 \\
97.788 \\
66.618 \\
31.203\end{array}$ \\
\hline
\end{tabular}

Around $30 \%$ of observations originated from thrice daily milked cows. The fixed effect parity was subdivided into four classes. Most observations were from cows in first and second parity. Observations from cows in forth and higher parity were combined in class $>3$. Highest number of parity was 10 . The fixed effect of calving season was subdivided into four classes. Observations from cows, which calved in 1997 were combined in one class of calving season. The year 1998 was subdivided into three calving classes (January to April, May to August, September to December). For each week of lactation between 6577 and 9905 observations were available for the traits activity, milk yield, milk flow rate and electrical conductivity. The fixed effect test day had between 280 and 321 classes.

Statistical analyses of data were performed by using the SAS procedure MIXED (SAS, 1992). The statistical model was as following:

$\mathrm{Y}_{\mathrm{ijklmno}}=\mu+\mathrm{P}_{\mathrm{i}}+\mathrm{CS}_{\mathrm{j}}+\mathrm{TDAY}_{\mathrm{k}}+\mathrm{M}_{\mathrm{l}}+(\mathrm{M} * \mathrm{LW})_{(\mathrm{i}) \mathrm{l}}+\mathrm{c}_{\mathrm{n}}+\mathrm{e}_{\mathrm{ijklmno}}$

where $\mathrm{Y}_{\mathrm{ijklmno}}$ is the observed value of the different traits and $\mu$ is the overall mean. The model considered the fixed effects parity $\left(\mathrm{P}_{\mathrm{i}}\right)$, season of calving $\left(\mathrm{CS}_{\mathrm{j}}\right)$, test day $\left(\mathrm{TDAY}_{\mathrm{k}}\right)$ and milking frequency $\left(\mathrm{M}_{\mathrm{l}}\right)$. An interaction between milking frequency and lactation week within parity $\left(\mathrm{M}^{*} \mathrm{LW}\right)_{(\mathrm{i}) \mathrm{m}}$ and the random effect of cow $\left(\mathrm{c}_{\mathrm{n}}\right)$ were implemented. The residual error was denoted by $\mathrm{e}_{\mathrm{ijklmn}}$. The suitability of the used 
model was verified by a plot of residuals. The structure of residuals fulfilled the assumption of homogeneity of variance. Extreme outlier did not occur and a transformation was not appropriate.

The repeatability (w) was estimated by relation of permanent and environmental variance between cows and phenotypic variance: $\mathrm{w}=\hat{\sigma}_{c}^{2}\left(\hat{\sigma}_{c}^{2}+\hat{\sigma}_{e}^{2}\right)^{-1}$. The variance between cows was denoted by $\hat{\sigma}_{c}^{2}$ and the residual by $\hat{\sigma}_{e}^{2}$.

\section{Results}

Least squared means from statistical analyses for the fixed effects milking frequency, parity and calving season are presented in Table 4.

Table 4

Influence of the fixed effects milking frequency, parity and calving season on the traits activity, milk yield, milk flow rate and electrical conductivity (Least squared means (LSM) and standard errors (SE)) (Einfluss der fixen Effekte Melkfrequenz, Laktationsnummer und Kalbesaison auf die Merkmale Bewegungsaktivität, Milchmenge, durchschnittliches Minutengemelk und elektrische Leitfähigkeit)

\begin{tabular}{|c|c|c|c|c|c|c|c|c|c|}
\hline & \multirow[t]{2}{*}{ Classes } & \multicolumn{2}{|c|}{ Activity*1 } & \multicolumn{2}{|c|}{ Milk yield $*^{2}$} & \multicolumn{2}{|c|}{ Milk flow rate $*^{2}$} & \multicolumn{2}{|c|}{$\begin{array}{c}\text { Electrical } \\
\text { conductivity }{ }^{2}\end{array}$} \\
\hline & & LSM & $\mathrm{SE}$ & LSM & SE & LSM & $\mathrm{SE}$ & LSM & $\mathrm{SE}$ \\
\hline \multirow[t]{4}{*}{ Parity } & 1 & $4.7^{\mathrm{a}}$ & 0.06 & $26.6^{\mathrm{a}}$ & 0.13 & $2.0^{\mathrm{a}}$ & 0.01 & $476^{\mathrm{a}}$ & 1.20 \\
\hline & 2 & $4.1^{\mathrm{b}}$ & 0.03 & $31.2^{\mathrm{b}}$ & 0.10 & $2.2^{\mathrm{b}}$ & 0.01 & $498^{b}$ & 0.92 \\
\hline & 3 & $3.9^{\mathrm{c}}$ & 0.04 & $32.6^{c}$ & 0.11 & $2.2^{\mathrm{c}}$ & 0.01 & $502^{c}$ & 0.99 \\
\hline & $>3$ & $3.9^{c}$ & 0.04 & $33.1^{d}$ & 0.13 & $2.2^{\mathrm{b}}$ & 0.01 & $511^{d}$ & 1.20 \\
\hline Calving & 1997 & $3.9^{\mathrm{a}}$ & 0.08 & $31.4^{\mathrm{a}}$ & 0.18 & $2.2^{\mathrm{a}}$ & 0.02 & $497^{\mathrm{ab}}$ & 1.65 \\
\hline \multirow[t]{3}{*}{ season } & 19981 & $4.1^{\mathrm{b}}$ & 0.05 & $31.3^{\mathrm{a}}$ & 0.17 & $2.1^{\mathrm{b}}$ & 0.02 & $495^{\mathrm{a}}$ & 1.54 \\
\hline & 19982 & $4.3^{\mathrm{b}}$ & 0.07 & $29.6^{\mathrm{b}}$ & 0.18 & $2.0^{\mathrm{C}}$ & 0.02 & $500^{\mathrm{b}}$ & 1.59 \\
\hline & 19983 & $4.2^{\mathrm{b}}$ & 0.08 & $31.2^{\mathrm{a}}$ & 0.19 & $2.1^{\mathrm{b}}$ & 0.02 & $497^{\mathrm{a}}$ & 1.69 \\
\hline Milking & 2 & $4.1^{\mathrm{a}}$ & 0.03 & $28.3^{\mathrm{a}}$ & 0.10 & $2.3^{\mathrm{a}}$ & 0.01 & $502^{\mathrm{a}}$ & 0.88 \\
\hline frequency & 3 & $4.2^{\mathrm{b}}$ & 0.04 & $33.5^{b}$ & 0.10 & $2.0^{\mathrm{b}}$ & 0.01 & $492^{b}$ & 0.93 \\
\hline
\end{tabular}

Means within a column with different superscripts differ (Bonferoni test)

$*^{1} \mathrm{P}<0.01$ for calving season, $\mathrm{P}<0.0001$ for other fixed effects

$*^{2} \mathrm{P}<0.0001$ for all fixed effects

With exception of the fixed effect calving season for the trait activity, all fixed effects were highly significant for all traits $(\mathrm{P}<0.0001)$. Activity decreased with increasing number of parity. Highest activity was calculated for cows in first parity with 4.7 contacts per hour. Activity of cows in second parity is reduced by $12.8 \%$ and activity of cows in third parity is reduced by $17 \%$ compared to activity in first parity. Activity of cows in third and higher parity was not significantly different.

Depending on the calving season activity ranges between 3.9 and 4.3. Lowest activity was measured for cows with calvings in 1997 and highest activity was measured for cows which calved in summer 1998. Measurements from cows which calved in 1998 did not differ significantly from each other.

Thrice daily milked cows showed an increase of activity of 3.2\% in comparison with twice daily milked cows.

For the trait milk yield an increase of $24.4 \%$ between the first and fourth class of parity was calculated. Milk yield of cows in first parity was $26.6 \mathrm{~kg}$ per day and for cows with more than three parities a least squared mean of 33.1 was calculated. All classes of parity were significantly different from each other. The different classes of the fixed effect calving season do not show a consistent trend for the trait milk yield. Despite the fact that cows with calvings in 1997 are in later lactation in the observation period than 
other cows, these cows showed the highest milk yield with $31.4 \mathrm{~kg}$ per day. This value was only statistically significantly different to the milk yield of cows with calvings between May and August 1998. With increasing milking frequency milk yield increased by $18.2 \%$ to $33.5 \mathrm{~kg}$ per day.

Milk flow rate was not consistently influenced by the fixed effect number of parity. Lowest milk flow rates originated from cows in first parity with $2.0 \mathrm{~kg}$ per minute. Milk flow rate increased by $8 \%$ in higher parities. Milk flow rate for cows in third parity was significantly different from milk flow rates of cows in lower or higher parities. No significant differences were found for milk flow rates for cows with calving periods from January to April and September to December 1998. Significantly lower milk flow rates were found for cows with calving in the summer period from May to August and significantly higher milk flow rates were calculated for cows with calving in 1997. With increasing milking frequency, milk flow rate decreased from 2.3 $\mathrm{kg}$ per minute to $2.0 \mathrm{~kg}$ per minute.

All classes of parity showed significantly different electrical conductivity. From first parity to more than three parities electrical conductivity increases by $7.4 \%$ to 511 units. Electrical conductivity was significantly higher for cows with a calving season between May and August 1998, than for cows in other calving seasons in 1998. A significantly higher electrical conductivity was calculated for cows which were milked twice daily.

As frequency of milking depends highly on the stage of lactation, this effect was considered additionally as interaction with parity and week of lactation (Figure 1).
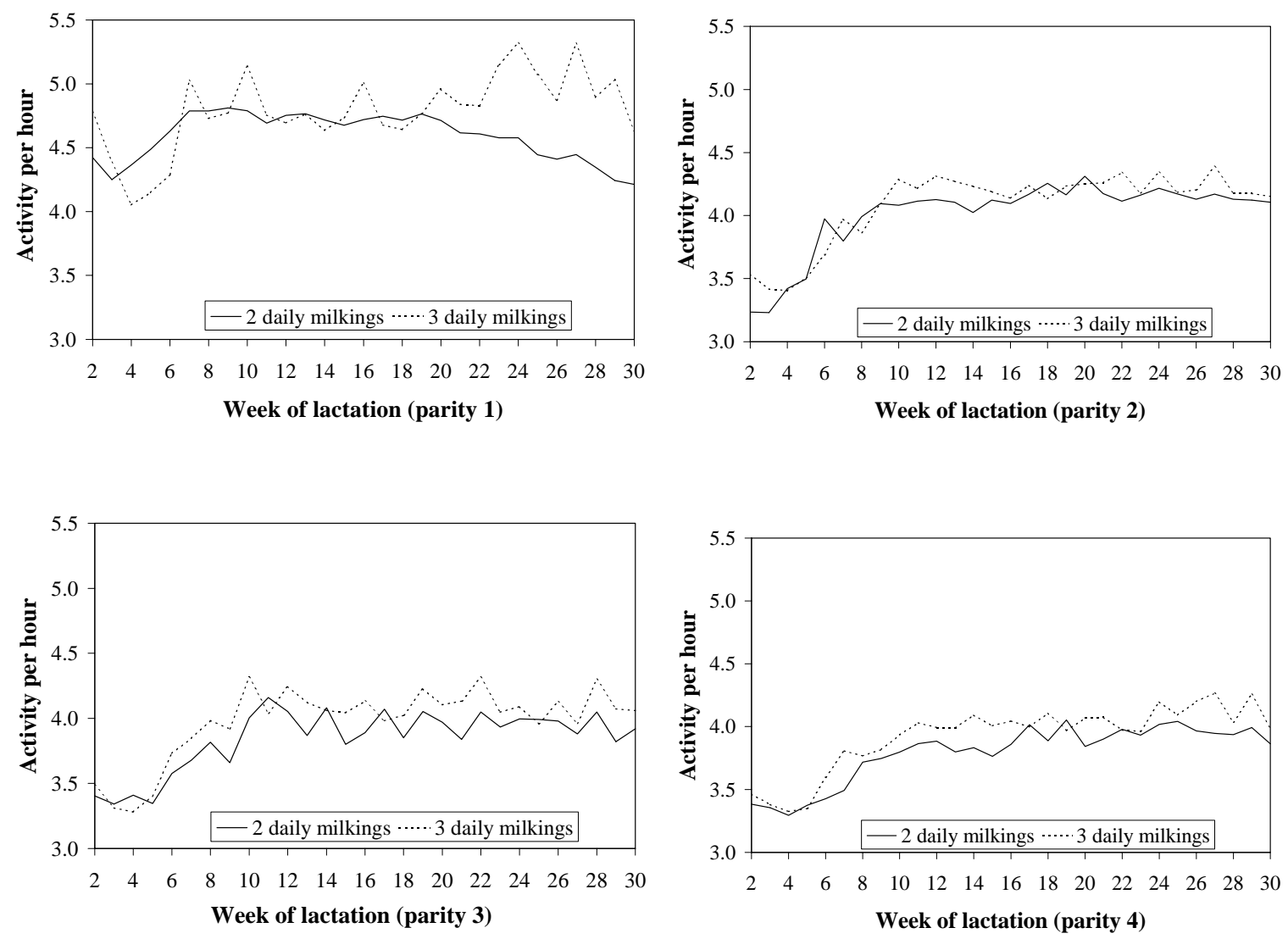

Fig. 1: Activity of dairy cows depending on the milking frequency and the week of lactation in different parities (Aktivitätsverlauf von Milchkühen in Abhängigkeit von der Melkfrequenz und der Laktationswoche in verschiedenen Laktationen) 
Independent from parity and frequency of milking, activity of all cows started at a high level in the second week of lactation. The minimum activity value for most curves was during the fourth week of lactation. Activity increased up from the sixth to the eighth week of lactation. Afterwards, level of activity fluctuates in cycles. Obvious highest activity rates can be seen for cows in first parity. Activity of these cows decreased from 4.8 in the ninth week of lactation to 4.2 in the $30^{\text {th }}$ week of lactation, if two daily milkings were performed. Cows with two parities showed slightly higher activity than cows in following parities. Activity of thrice daily milked cows was on the same level as activity from twice daily milked cows. Higher fluctuations for cows in first parity and for cows in higher parities in later weeks of lactation originate from low frequency of thrice daily milked cows.

Reduction of milk yield during lactation coincided with reduction of milk flow rate. Electrical conductivity was on a steady level during lactation of cows in first parity. For cows with higher parity, electrical conductivity in the second week of lactation started on a higher level and increased during lactation. This was more obvious for twice, than for thrice daily milked cows.

In Figure 2 the variation of the trait activity in process of test days can be seen.

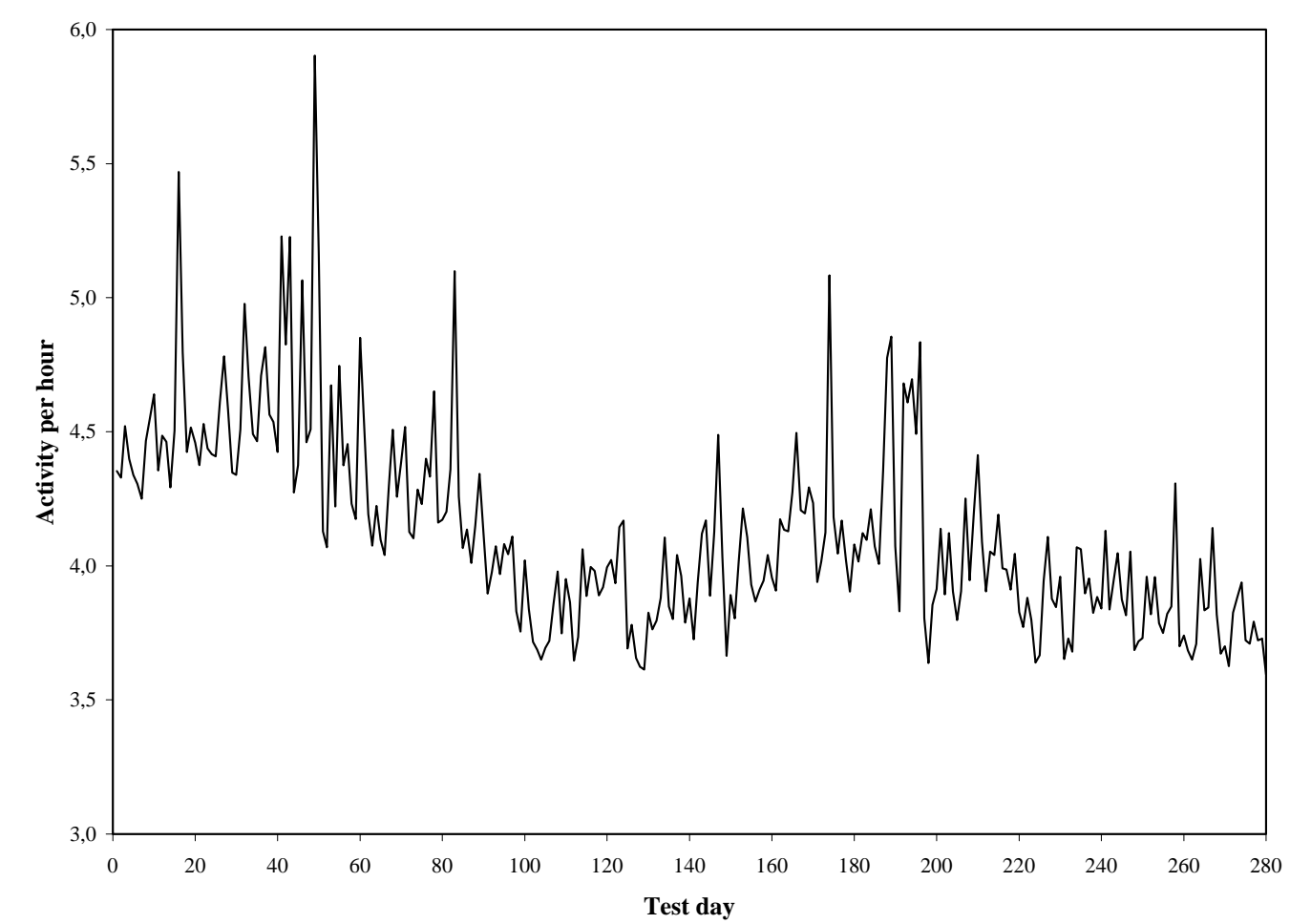

Fig. 2: Influence of the day of observation $(n=280)$ on activity of dairy cows (LSM) (Einfluss des Beobachtungstages auf die Bewegungsaktivität von Milchkühen)

The fixed effect test day combined effects of season, feeding and treatment of herd. Between successive days the least squared means varied in a high range. Variations were higher in the first 100 test days than in the following period.

Except for small fluctuations least squared means for milk yield, milk flow rate and electrical conductivity showed a steady level, independent from the day of observation.

Repeatability for the traits milk yield, milk flow rate and electrical conductivity was 70.0, 78.7 and $71.5 \%$, respectively (Table 5), and this points to characteristic patterns within cows. Repeatability for activity was $27.4 \%$. 
Table 5

Estimates of variance components and resulting repeatability for the traits activity, milk yield, milk flow rate and electrical conductivity (Schätzwerte für die Varianzkomponenten und die resultierende Wiederholbarkeit für die Merkmale Bewegungsaktivität, Milchmenge, durchschnittliches Minutengemelk und elektrische Leitfähigkeit)

\begin{tabular}{lccc}
\hline Trait & Variance between cows & Residual variance & Repeatability (\%) \\
\hline Activity & 1.15 & 3.03 & 27.4 \\
Milk yield & 18.11 & 7.78 & 70.0 \\
Milk flow rate & 0.19 & 0.05 & 78.7 \\
Electrical conductivity & 1538.80 & 613.50 & 71.5 \\
\hline
\end{tabular}

\section{Discussion}

In contrast to ARNEY et al. (1994), who found significantly greater locomotion rates in the afternoon and evening than in the morning, no differences between morning and evening measurements could be found. Activity from morning and evening measurements were both 3.8 units per hour. Additionally, least squared means for activity differed only by $3.2 \%$ between twice and thrice daily milked cows. In agreement with LEWIS and NEWMAN (1984) a daily value for activity was calculated for each cow. For the traits milk yield, milk flow rate and electrical conductivity a daily value was also estimated because milkings were performed all day and not only in defined milking periods. YANG (1998) analysed the trait milk yield as milk production per hour, because of a temporal difference between first and last milking of one hour. The author found significantly higher milk production rates in the evening than in the morning.

In agreement with results of GWAZDAUSKAS et al. (1983) activity was significantly effected by parity. Obvious highest values for activity were measured for cows in first parity. Probably, the increased activity of these cows was caused by the new environment after calving. The cows must adapt to the housing and milking system and must rank themselves within the herd. In later stage of lactation, activity of cows in first parity decreased. The level of activity in following parities was obviously lower. AT-TARAS and SPAHR (2001) were not able to detect significant differences in activity between parities.

The run of the curve for activity during lactation coincided with results of DE MOL (2000). The author reported that activity in the first 30 days of lactation is mostly on a lower level, than activity of cows in following lactation periods.

Cows with calvings in 1997 showed lowest activity because in the observation period, these cows were already adapted to the housing system and to the herd. Additionally, most of these cows were already pregnant and no oestrus related activity peaks occurred.

Thrice daily milked cows showed with 4.2 contacts per hour a significantly higher activity than twice daily milked cows with 4.1 contacts per hour. It was supposed that thrice daily milked cows require more time for consumption of food and water and for moving to the milking parlour than other cows.

High fluctuations of activity between test days might be caused by altered daily routines like hoof trimming, moderation of hot, humid weather and movement of cows to a new group. These assumptions are confirmed by KOELSCH et al. (1994).

As pointed out by WENDL and KLINDTWORTH (1997) each cow presents her individual activity pattern, depending on behaviour, ranking within herd, housing 
conditions, environmental conditions and farm specific parameters. In contrast to these results repeatability for activity was $27.4 \%$. Accordingly, measurements within cow were not strongly related. One reason might be the increased activity during oestrus, as confirmed by KIDDY (1977). Between oestrus, activity cycles with smaller fluctuations.

The repeatability for the traits milk yield, milk flow rate and electrical conductivity ranged between 70 and $87.7 \%$. These values point to a good quality of collected data and conform with earlier results. REENTS et al. (1995) found repeatabilities for milk yield from first to third parity between 63.5 to $66.6 \%$. For the trait milk flow rate a repeatability of $86 \%$ was found by PETERSEN et al. (1986).

The distribution of the trait activity gives an indication that this trait might be suitable for oestrus detection. Values which cause the right skewness should be analysed in particular. In the case where these observations are caused during oestrus periods and not by environmental changes, activity might be a promising trait for oestrus detection. The pattern of milk yield, milk flow rate and electrical conductivity during lactation coincided with earlier results of SÜPHKE (1988), PEREZ-GUZMAN (1985) and LINZELL and PEAKER (1975). The high increase of milk yield for thrice daily milked cows can be explained by the management of the herd. Especially, cows in early lactation and cows with high milk yield were milked thrice daily.

\section{Conclusion}

By statistical analyses, significant influences of the fixed effects parity, calving season, week of lactation, test day and milking frequency on the traits activity, milk yield, milk flow rate and electrical conductivity were found. The right skewed distribution of the trait activity indicated, that this trait might be a suitable parameter for oestrus detection.

With regard to the statistically significant differences for the fixed effects considered for the trait activity, automatic oestrus detection should be performed separately for each cow. The different levels of activity measurements between cows lead to the suggestion that oestrus detection should be conducted on basis of relative deviations.

This investigation showed that the automatic collection of production data on commercial dairy farms is possible. The structure of data is satisfying for further calculation as it was verified by the repeatabilities of the milking parameters. The repeatability of the trait activity indicated high differences between and within cows.

\section{References}

ARNEY, D.R.; KITWOOD, S.E.; PHILLIPS, C.J.C.:

The increase in activity during oestrus in dairy cows. Appl. Anim. Behav. Sci., 40 (1994), 211-218

AT-TARAS, E.E.; SPAHR, S.L.:

Detection and characterisation of oestrus in dairy cattle with an electronic heatmount detector and an electronic activity tag. J. Dairy Sci., 84 (2001), 792-798

BOICHARD, D.:

Estimation of the economic value of conception rate in dairy cattle. Livest. Prod. Sci., 24 (1990), 187204

BRITT, J.H.:

Enhanced reproduction and its economic implications. J. Dairy Sci., 68 (1985), 1585-1592

DE MOL, R.M.:

Automated detection of oestrus and mastitis in dairy cows. Proefschrift Wageningen, The Netherlands (2000) 
ERADUS, W.J.; ROSSING, W.; HOGEWERF, P.H.; BENDERS, E.:

Signal processing of activity data for oestrus detection in dairy cattle. In: IPEMA, LIPPUS, METZ, ROSSING (Eds.): Proceedings of the international symposium on prospects for automatic milking. EAAP Publication No. 65, (1992) Pudoc Scientific Publishers, Wageningen, The Netherlands: 360-369

FIRK, R.; STAMER, E.; JUNGE, W.; KRIETER, J.:

Automation of oestrus detection in dairy cows: a review. Livest. Prod. Sci., (2001), accepted

GWAZDAUSKAS, F.C.; LINEWEAVER, J.A.; MCGILLIARD, M.L.:

Environmental and management factors affecting oestrous activity in dairy cattle. J. Dairy Sci., 66 (1983), 1510-1514

KIDDY, C.A.:

Variation in physical activity as an indicator of oestrus in dairy cows. J. Dairy Sci., 60 (1977), 235-243

KOELSCH, R.K.; ANESHANSLEY, D.J.; BUTLER, W.R.:

Analysis of activity measurement for accurate oestrus detection in dairy cattle. J. Agric. Eng. Res., 58 (1994), 107-114

LEWIS, G.S.; NEWMAN, S.K.:

Changes throughout oestrous cycles of variables that might indicate oestrus in dairy cows. J. Dairy Sci., 67 (1984), 146-152

LINZELL, J.L.; PEAKER, M.:

Efficacy of the measurement of the electrical conductivity of milk for the detection of subclinical mastitis in cows: detection of infected cows at a single visit. Br. Vet. J., 131 (1975), 447-460

MACK, G.:

Wirtschaftlichkeit des züchterischen Fortschritts in Milchviehherden - Gesamtbetriebliche Analyse mit Hilfe eines simultan-dynamischen linearen Planungsansatzes. Univ. Hohenheim, Diss., 1996

PEREZ-GUZMAN, M.D.:

Untersuchungen zur Melkbarkeit beim Rind „Modellstudien und genetische Analyse“. Univ. Kiel, Diss., 1985

PETERSEN, M.L.; HANSEN, L.B.; YOUNG, C.W.; MILLER, K.P.:

Rates of milk flow and milking times resulting from selection for milk yield. J. Dairy Sci., 69 (1986), 556-563

REENTS, R.; JAMROZIK, J.; SCHAEFFER, L.R.; DEKKERS, J.C.M.:

Estimation of genetic parameters for test day records of somatic cell score. J. Dairy Sci., 78 (1995), 2847-2857

SAS:

SÜPHKE, E.H.:

SAS Language Reference, Version 6. (1992), SAS Institut Inc., Cary, NC, USA

Stoffwechselparameter, Milchleistung und Futteraufnahme bei Deutschen Schwarz- und Rotbunten Kühen. Univ. Kiel, Diss., 1988

WENDL, G.; KLINDTWORTH, K.:

Einsatz von elektronischen Schrittzählern (Pedometer) zur Brunsterkennung bei Milchkühen. In: Bau, Technik und Umwelt in der landwirtschaftlichen Nutztierhaltung, Beiträge zur 3. Internationalen Tagung 1997, Kiel, 11.-12. März 1997, Hrsg.: Inst. für Landw. Verfahrenstechnik der ChristianAlbrechts-Universität Kiel, 1997

WILLIAMS, W.F.; YVER, D.R.; GROSS, T.S.: YANG, Y.:

Comparison of estrus detection techniques in dairy heifers. J. Dairy Sci., 64 (1981), 1738-1741

Rechnergestützte Östrusüberwachung bei Milchkühen unter Anwendung der Fuzzy - Logic - Methode. Herbert Utz Verlag, Wissenschaft, München (1998)

Received: 2001-11-05

Accepted: 2002-04-17

Author's address

Dipl.-Ing. agr. REGINA FIRK, Dr. ECKHARD STAMER,

Dr. WOLFGANG JUNGE, Prof. Dr. habil. JOACHIM KRIETER

Institut für Tierzucht und Tierhaltung der Christian-Albrecht-Universität zu Kiel

Olshausenstr. 40

D-24098 Kiel

Germany 